\title{
PENGARUH PROPORSI LESITIN DAN SUSU SKIM SEBAGAI EMULSIFIER TERHADAP KARAKTERISTIK HARD CANDY TOFFEE
}

\author{
(Effects of Lecithin and Skim Milk Addition as Emulsifier of Hard Candy \\ Toffee's Characteristics)
}

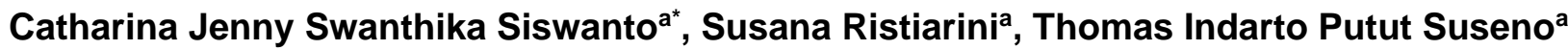 \\ ${ }^{a}$ Fakultas Teknologi Pertanian, Universitas Katolik Widya Mandala Surabaya, Indonesia \\ ${ }^{*}$ Penulis korespondensi \\ Email: Anastasia.cathe96@gmail.com
}

\begin{abstract}
Hard candy toffee is a mixture of sugar, glucose syrup, milk, and fat which is a water in oil emulsion. Emulsifier is important to maintain the emulsion stability in hard candy toffee. Skim milk and lecithin can be used as emulsifier for hard candy toffee. This research is aimed to determine the effects of lecithin and skim milk addition of hard candy toffee's physicochemical and sensory properties. This research used Randomized Block Design with one factor, which was concentration of lecithin and concentration of skim milk $(P)$, which has seven levels on each level: $0.7: 0 \%(P 1) ; 0.6: 0.1 \%\left(P_{2}\right) ; 0.5: 0.2 \%(P 3)$; 0.4:0.3\%(P4); 0.3:0.4\%(P5); 0.2:0.6\%(P6); dan 0.1:0.6\%(P7). Parameters that are tested included analysis of physicochemical properties which are water content, color, hardness, fracturability, and emulsion stability and analysis of sensory properties which are flavor, color and texture. Data will be analyzed using Analysis of Variance (Anova) at $\alpha=5 \%$. If there is an effect of lecithin and skim milk addition on parameters that are tested, then it will be continued with Duncan's Multiple Range Test (DMRT) on $\alpha=5 \%$. The result show that hard candy toffee has water content of 0.38-0.68; hardness

7,952-16,421 g.Force; lightness 44.02-55.63; chroma 10.93-17.50; Ohue 51.78 - 56.16. Best treatment in sensory evaluation is the usage of lecithin concentration of $0.1 \%$ dan skim milk concentration of $0.6 \%$ which result in color, texture and flavor value are $4.41 ; 4.83$; and 4.89 that means neutral until slightly preferred.
\end{abstract}

Keywords: hard candy toffee, lecithin, skim milk

\begin{abstract}
ABSTRAK
Permen toffee terbuat dari campuran gula pasir, sirup glukosa, susu, dan lemak yang merupakan emulsi lemak dalam air. Emulsifier memegang peranan penting pada permen toffee untuk menjaga kestabilan emulsinya. Emulsifier yang digunakan adalah susu skim dan lesitin. Tujuan dari penelitian ini adalah untuk mengetahui pengaruh proporsi lesitin dan susu skim terhadap sifat fisikokimia dan sensoris hard candy toffee. Penelitian menggunakan Rancangan Acak Kelompok dengan satu faktor, yaitu konsentrasi lesitin dan konsentrasi susu skim $(P)$ yang terdiri atas tujuh taraf: 0,7:0\% $\left(P_{1}\right) ; 0,6: 0,1 \%\left(P_{2}\right) ; 0,5: 0,2 \%$ $\left(P_{3}\right) ; 0,4: 0,3 \%\left(P_{4}\right) ; 0,3: 0,4 \%\left(P_{5}\right) ; 0,2: 0,6 \%\left(P_{6}\right)$; dan 0,1:0,6\% $\left(P_{7}\right)$ dan diulang sebanyak empat kali. Parameter pengujian meliputi kadar air, kestabilan emulsi, tekstur (kekerasan dan daya patah), warna dan kesukaan yang meliputi warna, tekstur, dan rasa. Data yang diperoleh dianalisis dengan uji Analysis of Variance (Anova) pada $\alpha=5 \%$. Apabila terdapat perbedaan nyata antar perlakuan, maka dilanjutkan dengan uji Duncan's Multiple Range Test (DMRT) pada $\alpha=5 \%$. Hasil penelitian kadar air hard candy toffee 0,68-3,06; tingkat kekerasan 7.952-16.421 g.Force; nilai lightness 44,02-55,63; nilai chroma 10,93-
\end{abstract}


17,50; dan nilai ${ }^{\circ}$ hue $51,78-56,16$. Proporsi lesitin dan susu skim terbaik berdasarkan organoleptik adalah $\mathrm{P}_{6}(4,89)$ yang berarti netral hingga agak suka.

Kata kunci: hard candy toffee, lesitin, susu skim

\section{PENDAHULUAN}

Hard candy toffee tergolong permen non kristal yang terbuat dari gula pasir, sirup, glukosa, susu lemak, dan kemudian dilakukan pemekatan campuran dan pemasakan hingga mencapai suhu $149^{\circ} \mathrm{C}$ $154^{\circ} \mathrm{C}$ (hard crack stage). Produk toffee merupakan salah satu bentuk emulsi lemak dalam air. Penambahan emulsifier bertujuan untuk mencampurkan mentega dan air yang merupakan bahan utama hard candy toffee untuk membentuk suatu emulsi yang stabil. Oiling out akan terjadi apabila emulsi tidak stabil, sehingga permen yang dihasilkan akan tampak lapisan minyak.

Penggunaan emulsifier dengan proporsi yang tepat diperlukan untuk memperoleh karakteristik toffee yang baik. Jenis emulsifier yang dapat ditambahkan adalah susu skim dan lesitin. Pemilihan emulsifier didasarkan pada nilai HLB (hydrophilic-lipophilic balance).

Penggunaan emulsifier secara tunggal belum memberikan karakteristik toffee yang baik pada penelitian yang telah dilakukan. Penambahan emulsifier susu skim sebesar 0,7\% secara tunggal pada adonan menghasilkan permen yang tidak berminyak dengan warna cokelat yang sedikit pucat, aroma yang kurang dapat diterima dan tekstur permen yang menjadi lebih lengket. Proporsi antara lesitin dan susu skim sebagai emulsifier perlu dilakukan untuk menghasilkan hard candy toffee yang lebih baik. Penelitian ini ingin mengetahui bagaimana pengaruh proporsi susu skim dan lesitin sebagai emulsifier dalam pembuatan permen toffee. Maka perlakuan proporsi susu skim dengan lesitin dalam penelitian ini adalah sebagai berikut: 0,7\%:0\%; 0,525\%:0,175\%; 0,35\%:0,35\%; 0,175\%:0,525\% dan 0\%:0,7\%.

\section{BAHAN DAN METODE}

\section{Bahan}

Bahan-bahan yang digunakan dalam penelitian ini adalah gula pasir, mentega, lesitin yang didapat dari Toko Multi Aroma, susu skim yang didapat dari UD. Matahari, dan air minum dalam kemasan (AMDK). Bahan-bahan analisa yang digunakan dalam penelitian ini adalah akuades.

\section{Pembuatan Hard Candy Toffee}

Proses pembuatan hard candy toffee diawali dengan pelarutan gula pasir hingga terbentuk larutan kental. Pelarutan gula pasir dilakukan dengan cara pemanasan gula pasir dan air hingga suhu mencapai $110^{\circ} \mathrm{C}$. Pemanasan butter juga dilakukan hingga meleleh. Butter yang telah meleleh dicampurkan dengan emulsifier dengan konsentrasi tertentu. Bahan-bahan yang tercampur tersebut kemudian diaduk hingga merata. Campuran bahan tersebut dicampurkan dengan larutan gula kental. Pemasakan bahan-bahan dilakukan dengan menggunakan panci stainless steel hingga mencapai suhu $149^{\circ} \mathrm{C}$ (fase hard crack) pada kondisi api sedang. Pengadukan tidak dapat dilakukan selama proses pemasakan karena dapat memicu pembentukan kristal kembali sehingga tekstur permen yang dihasilkan berpasir. Setelah mencapai tahap hard crack, pengadukan dilakukan kembali secara perlahan untuk meratakan warna permen yang terbentuk. Pencetakan dilakukan setelah proses pemasakan dengan menggunakan cetakan silikon yang berbentuk lingkaran. Pendinginan dilakukan setelah pencetakan di suhu ruang selama kurang lebih 10 menit. Adonan permen yang sudah dingin dikeluarkan dari cetakan silikon. Penyimpanan permen dilakukan setelah permen telah dingin dalam plastik dan diberi desikan berupa silica gel. 


\section{Analisis Statistik}

\begin{abstract}
Rancangan percobaan yang
digunakan adalah Rancangan Acak
Kelompok (RAK) faktorial dengan satu faktor, yaitu proporsi konsentrasi lesitin dan konsentrasi susu skim yang terdiri atas tujuh taraf, yaitu 0,7:0\% $\left(\mathrm{P}_{1}\right) ; 0,6: 0,1 \%\left(\mathrm{P}_{2}\right)$; 0,5\%:0,2\% $\left(\mathrm{P}_{3}\right) ; 0,4: 0,3 \%\left(\mathrm{P}_{4}\right) ; 0,3: 0,4\left(\mathrm{P}_{5}\right)$; 0,2\%:0,6\% $\left(P_{6}\right)$; dan 0,1\%:0,6\% $\left(P_{7}\right)$ dan diulang sebanyak empat kali. Data yang diperoleh akan dianalisa dengan uji Analysis of Variance (ANOVA) pada $\alpha=5 \%$. Apabila terdapat perbedaan nyata antar perlakuan, maka dilanjutkan dengan uji Duncan's Multiple Range Test (DMRT) pada $\alpha=5 \%$.
\end{abstract}

\section{Metode Analisa}

Analisa yang dilakukan meliputi pengujian kadar air dengan metode thermogravimetri (AOAC, 1995), kestabilan emulsi dengan mikroskop (Floury et al., 2013), tekstur dengan Texture Analyzer (Gadiyaram dan Kannan, 2004), warna dengan color reader Minolta CR-10 (Xrite, 2015), sifat organoleptik meliputi warna, tekstur, dan rasa, dan penentuan perlakuan terbaik berdasarkan hasil uji organoleptik dengan metode spiderweb.

\section{HASIL DAN PEMBAHASAN}

Hasil penelitian setiap parameter hard candy toffee dari berbagai perlakuan dapat dilihat pada Tabel 1. Perhitungan kadar air hard candy toffee dinyatakan dalam persen berat basah. Menurut Wills (1998) kadar air hard candy pada umumnya adalah sekitar 0,5-2,0\%. Kadar air hard candy umumnya adalah sekitar 2-5\% (Ergun et al., 2010). Hasil pengujian menunjukkan bahwa kadar air rata-rata hard candy toffee berkisar antara $0,68 \%$ hingga $3,06 \%$, hal tersebut sesuai dengan rentang kadar air hard candy pada umumnya. Hasil pengujian ANOVA dengan $\alpha=5 \%$ menunjukkan bahwa proporsi antara lesitin dan susu skim memberikan pengaruh beda nyata sehingga pengujian dilanjutkan dengan uji DMRT untuk mengetahui perbedaan nyata dari tiap perlakuan. Kadar air hard candy toffee tertinggi adalah perlakuan dengan proporsi konsentrasi susu skim sebesar $0,6 \%$ dan konsentrasi lesitin sebesar $0,1 \%$ (P7) yaitu $3,06 \%$. Konsentrasi susu skim berpengaruh terhadap kadar air hard candy toffee. Proses pemanasan pada suhu tinggi menyebabkan struktur protein terbuka, sehingga jumlah air yang terikat oleh protein banyak. Peristiwa tersebut meningkatkan kapasitas protein untuk mengikat air. Protein yang mengandung asam amino sistein dan sistin akan mengalami polimerisasi melalui reaksi pertukaran sulfhidril-disulfida selama pemanasan dan membentuk jaringan kovalen berkelanjutan setelah pendinginan (Andic et al. 2010). Pemanasan juga akan menyebabkan isomerasi laktosa menjadi laktulosa yang lebih mudah larut. Komponen-komponen yang berperan dalam pengikatan air pada susu skim adalah karbohidrat dan protein yaitu berupa laktulosa serta kasein dan protein whey.

Perlakuan dengan konsentrasi lesitin 0,7\% tanpa penambahan susu skim ( $\mathrm{P} 1)$ menunjukkan droplet lemak dan air yang saling berdekatan mengindikasikan terjadinya coalescence pada emulsi hard candy toffee yang didahului dengan creaming. Perlakuan dengan konsentrasi lesitin sebesar $0,6 \%$ dan konsentrasi susu skim $\quad 0,1 \% \quad(\mathrm{P} 2)$ menunjukkan ukuran droplet lemak dan air masih belum seragam. Terdapat droplet lemak yang berukuran sangat besar dibandingkan dengan droplet lainnya. Munculnya droplet tersebut mengindikasikan terjadinya peristiwa ostwald ripening. Perlakuan dengan konsentrasi lesitin $0,2 \%$ dan konsentrasi susu skim $0,5 \% \quad$ (P6) menunjukkan perubahan ukuran droplet lemak dan air menjadi lebih besar dan indikasi terjadinya disproportionation. Gambar 1 menunjukkan hasil pengujian 
Tabel 1. Hasil Penelitian Setiap Parameter dari Berbagai Perlakuan

\begin{tabular}{lccccccc}
\hline \multirow{2}{*}{ Parameter } & \multicolumn{7}{c}{ Perlakuan } \\
\cline { 2 - 7 } & $\mathrm{P}_{1}$ & $\mathrm{P}_{2}$ & $\mathrm{P}_{3}$ & $\mathrm{P}_{4}$ & $\mathrm{P}_{5}$ & $\mathrm{P}_{6}$ & $\mathrm{P}_{7}$ \\
\hline Kadar Air (\%) & $0,68^{\mathrm{a}}$ & $1,31^{\mathrm{b}}$ & $1,50^{\mathrm{c}}$ & $1,98^{\mathrm{d}}$ & $2,23^{\mathrm{e}}$ & $2,78^{\mathrm{f}}$ & $3,06^{\mathrm{g}}$ \\
Hardness (g.Force) & $16.421^{\mathrm{f}}$ & $15.665^{\mathrm{e}}$ & $12.482^{\mathrm{d}}$ & $11.672^{\mathrm{c}}$ & $11.019^{\mathrm{c}}$ & $9.559^{\mathrm{b}}$ & $7.952^{\mathrm{a}}$ \\
Lightness (L) & $55,63^{\mathrm{f}}$ & $53,39^{\mathrm{e}}$ & $51,54^{\mathrm{d}}$ & $50,03^{\mathrm{c}}$ & $46,58^{\mathrm{b}}$ & $46,07^{\mathrm{b}}$ & $44,02^{\mathrm{a}}$ \\
Redness (a*) & 6,36 & 7,07 & 7,50 & 7,90 & 8,53 & 9,14 & 10,13 \\
Yellowness (b*) & 8,88 & 9,16 & 9,70 & 11,20 & 12,68 & 13,83 & 14,26 \\
Chroma (C) & $10,93^{\mathrm{a}}$ & $11,57^{\mathrm{b}}$ & $12,27^{\mathrm{c}}$ & $13,71^{\mathrm{d}}$ & $15,29^{\mathrm{e}}$ & $16,59^{\mathrm{f}}$ & $17,50^{\mathrm{g}}$ \\
Hue (h) & $54,40^{\mathrm{ab}}$ & $52,34^{\mathrm{a}}$ & $52,25^{\mathrm{a}}$ & $54,79^{\mathrm{b}}$ & $56,07^{\mathrm{b}}$ & $56,53^{\mathrm{b}}$ & $54,62^{\mathrm{b}}$ \\
Kesukaan warna & 3,95 & 3,99 & 4,10 & 4,14 & 4,36 & 4,29 & 4,41 \\
Kesukaan tekstur & 4,15 & 4,19 & 3,94 & 4,34 & 4,31 & 4,65 & 4,83 \\
Kesukaan rasa & 4,83 & 4,76 & 4,98 & 4,94 & 5,28 & 5,15 & 4,89 \\
\hline
\end{tabular}

kestabilan emulsi dengan mikroskop pada M100.

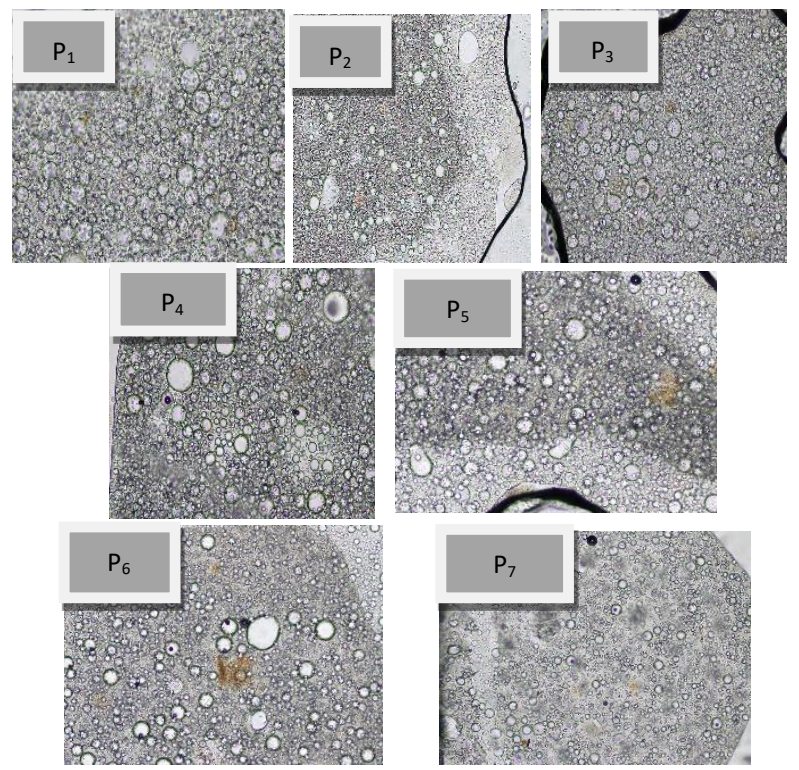

Gambar 1. Hasil Pengujian Kestabilan

Emulsi dengan Mikroskop pada M100

Perlakuan dengan konsentrasi lesitin $0,5 \%$ dan konsentrasi susu skim 0,2\% (P3), perlakuan dengan konsentrasi lesitin $0,4 \%$ dan konsentrasi susu skim 0,3\% (P4) dan perlakuan dengan konsentrasi lesitin 0,3\% dan konsentrasi susu skim 0,4\% (P5) menunjukkan kenampakan yang serupa, yaitu distribusi droplet lemak dan air yang lebih merata dan tidak menunjukkan indikasi terjadinya peristiwa ketidakstabilan emulsi. Perlakuan dengan konsentrasi lesitin $0,1 \%$ dan konsentrasi susu skim 0,6\% (P7) juga tidak menunjukkan indikasi terjadinya ketidakstabilan emulsi, namun ukuran droplet lemak dan air lebih kecil dan lebih seragam dibandingkan dengan perlakuan P3, P4, dan P5. Penggunaan molekul emulsifier efektif menghasilkan droplet lemak dan air berukuran lebih kecil, (Rao dan Mc Clements, 2010). Penggabungan kedua jenis emulsifier menunjukkan kestabilan emulsi yang sangat baik. Rasio air dan lemak yang digunakan dalam pembuatan hard candy toffee adalah sama, sehingga memerlukan emulsifier susu skim dan lesitin yang dapat menjaga kestabilan emulsi hard candy toffee. Perlakuan dengan konsentrasi lesitin sebesar $0,1 \%$ dan konsentrasi susu skim sebesar 0,6\% (P7) menunjukkan ukuran droplet yang paling kecil dan seragam. Kombinasi antara fosfolipid dengan kasein dan $\beta$-laktoglobulin pada protein susu skim memiliki kemampuan yang baik sebagai emulsifier sehingga mampu mempertahankan emulsi dalam hard candy toffee.

Perlakuan yang memiliki tingkat kesukaan panelis yang tinggi adalah perlakuan $\mathrm{P} 7$ yaitu perlakuan dengan konsentrasi lesitin $0,1 \%$ dan konsentrasi 
susu skim 0,6\%. Hasil pengujian tekstur hard candy toffee secara obyektif dengan texture analyzer menunjukkan bahwa penambahan susu skim akan membuat tekstur permen menjadi lebih lunak. Panelis lebih menyukai tekstur permen yang semakin lunak, karena pada umumnya hard candy toffee dikonsumsi dengan cara dikunyah. Tekstur yang lunak memudahkan pengunyahan permen toffee saat dikonsumsi.

Perlakuan proporsi lesitin dan susu skim yang paling disukai oleh panelis adalah P5 dengan konsentrasi lesitin 0,3\% dan konsentrasi susu skim 0,4\%. Rasa yang ditimbulkan pada hard candy toffee dipengaruhi oleh adanya reaksi-reaksi yang terjadi. Proses pemasakan hard candy toffee dilakukan pada suhu tinggi, hal tersebut menyebabkan terjadinya reaksi karamelisasi dan reaksi maillard. Reaksi karamelisasi akan menghailkan senyawa volatil seperti aldehid dan keton yang mengeluarkan aroma khas caramel (Powrie et al. 1986). Pemanasan karbohidrat dengan asam amino akan membentuk senyawa reaktif yang nantinya membentuk senyawa volatil heterosiklik. Senyawa volatil hetersiklik yang terbentuk sangat sedikit. Perlakuan yang berbeda-beda tidak menunjukkan adanya perbedaan, sehingga hasil pengujian tidak menunjukkan beda nyata.

Perlakuan terbaik ditentukan dari perhitungan luasan area terbesar. Perlakuan P7 dengan konsentrasi lesitin $0,1 \%$ dan konsentrasi susu skim $0,6 \%$ merupakan perlakuan terbaik dengan luasan area terbesar berdasarkan tingkat kesukaan panelis. Nilai kesukaan panelis terhadap warna, tekstur, dan rasa secara berturut-turut pada P7 adalah 4,41 dan 4,83; dan 4,89. Penambahan susu skim akan meningkatkan rasa dan warna dari hard candy toffee. Reaksi maillard yang terjadi antara gugus amina dari susu skim dengan gugus gula reduksi akan memunculkan aroma dan rasa yang lebih enak, sehingga lebih disukai oleh panelis.

\section{KESIMPULAN}

Perbedaan proporsi lesitin dan susu skim sebagai emulsifier memberikan pengaruh beda nyata terhadap sifat fisikokimia, yaitu kadar air, kestabilan emulsi, tekstur (kekerasan dan daya patah), dan warna hard candy toffee. Kadar air hard candy toffee adalah 0,68 hingga 3,06; tingkat kekerasan hard candy toffee adalah 7.952 hingga 16.421; nilai lightness hard candy toffee adalah 44,02 hingga 55,63; nilai chroma hard candy toffee adalah 10,93 hingga 17,50; dan nilai hue hard candy toffee adalah 51,78 hingga 56,16. Perbedaan proporsi lesitin dan susu skim sebagai emulsifier tidak memberikan pengaruh beda nyata terhadap sifat organoleptik yang meliputi warna, tekstur, dan rasa. Perlakuan terbaik berdasarkan tingkat kesukaan adalah perlakuan dengan konsentrasi lesitin $0,1 \%$ dan konsentrasi susu skim 0,6\% dengan nilai kesukaan terhadap parameter warna, tekstur, dan rasa secara berturut-turut adalah 4,$41 ; 4,83$; dan 4,89 .

\section{DAFTAR PUSTAKA}

Andic, S., O. Zorba, dan Y. Tuncturk. 2010. Effect of Whey Powder, Skim Milk Powder and Their Combination on Yield and Textural Properties of Meat Patties, International Journal of Agriculture \& Biology, 12:871- 876

Dairy For Global Nutrition. 2005. Nutritional Composition of Skim Milk Powder. Arlington: U.S. Dairy Export Council. 
Davies, C.G.A. dan T.P. Labuza. 2007. The Maillard Reaction Application to Confectionery Products. Minnesota: University of Minnesota.

Ergun, R., R. Lietha, dan R.H. Wartel. 2010. Moisture and Shelf Life in Sugar Confections, Critical Review in Food Science and Nutritions, 50:162- 192

Evanuarini, H., Nurliyani, Indratiningsih, dan P. Hastuti. 2016. Kestabilan Emulsi dan Karakteristik Sensoris Low Fat Mayonnaise dengan Menggunakan Kefir Sebagai Emulsifier Replacer, Jurnal IImu dan Teknologi Hasil Ternak, 11(2):53-59

Moeljaningsih. $2010 . \quad$ Pengaruh Penambahan Lesitin Terhadap Kualitas Permen Cokelat Selama Penyimpanan pada Suhu Kamar, Laporan Penelitian, Baristand Industri Surabaya.

Powrie, W.D., W.H. Chiu, dan V. P. Molund. 1986. Browning Reaction Systems as Sources of Mutagens and Antimutagens, Environmental Health Perspective, 67:47-54.
Rao, J.J. dan D.J. McClements. 2010. Stabilization of Phase Inversion Temperature Nanoemulsions by Sufactant Displacement, J. Agr. Food Chem, 55:7059-7066

Suseno, T.I.P., N. Fibria, dan N. Kusumawati. 2008. Pengaruh Penggantian Sirup Glukosa dengan Sirup Sorbitol dan Penggantian Butter dengan Salatrim terhadap Sifat Fisikokimia dan Organoleptik Kembang Gula Karamel, Jurnal Teknologi Pangan dan Gizi, 7(1):1-18.

Wills, D. 1998. Water Activity and Its Importance in Making Candy, National AACT Technical Seminar, Agustus 1998. 